\title{
D. M. MACKAY
}

Duncan Matheson Mackay was a versatile ophthalmologist, who found time to pursue antiquarian and historical interests, and to play an active part in the work of the Presbyterian Church, as well as leading a busy professional life. . He was for many years a familiar figure in the North of England Ophthalmological Society, of which he was chosen President in 1933. Among the other institutions which benefited from his activities are the British Medical Association, the Hull Medical Society, and Hull University College. His retirement from the staff of the Hull Royal Infirmary in 1929 was not destined to be permanent, because he returned in 1939 to fill a gap. Throughout the devastation of bombing raids, which incidentally destroyed his own home and equipment, Dr. Mackay continued to serve the Infirmary. In 1945 he returned to Scotland, and went on practising in Glasgow until a short time ago. He was in his 80th year when he died on April 12 at Campbeltown, Argyllshire. Among the ranks of ophthalmologists are many who will gratefully recall Dr. D. M. Mackay's courteous encouragement, and will remember with admiration his record of loyal service.

\section{BOOK NOTICE}

Text-Book of Ophthalmology. By. SIR W. STEwart DUkE-

Elder. Vol. IV. Pp. xxiv and 1157, 1081 illustrations, including

71 in colour. Henry Kimpton, (London). 1949. Price, £3 100.

It is more than twenty years since Parsons* wrote: "We can imagine a demon at each level who would know everything about every level below his own, and nothing about higher levels except what was dependent directly upon the known processes of his own and lower levels. Above the top we can imagine a super-demon who would know everything." Almost we could be persuaded, as we glide through the pages of this magnificent volume, that here at last we are face to face with the super-demon. The author himself is a modest man, who would be the first to proclaim the limitations of his knowledge. Nevertheless the illusion of a super-demon persists. - There is something uncanny in the notion of a mortal endowed with the swiftness and concentration of effort that must have gone to the making of so great a work. The achievement would be astonishing if it were the culmination of many years' whole-time effort, but the fact that this text-book has been written

*Parsons, J. H. Introduction to the Theory of Perception. Cambridge. 1927. 